\title{
History and the Politics of Nostalgia
}

\author{
Marcos Piason Natali
}

In 1688 the Swiss doctor Johannes Hofer published a tract in which, after considering the terms nostomania and philopatridomania, he settles on a combination of the Greek words nostos and algos to describe the pain resulting from the desire to return to one's home (381). Thus the word nostalgia was born, in a text claiming that a properly scientific term was lacking in order to accurately identify a condition that Hofer insisted was a clinical entity and, as such, was above all of medical interest. Throughout eighteenth-century Europe the word would gradually be adopted by specialists and laypeople alike to describe a disease provoked by excessive attachment to a distant homeland, a condition at first thought to be common particularly among natives of mountainous regions. By the end of the eighteenth century, the notion was expanded to include pathological attachment to any faraway place and, later, to distant times and persons.

The fact that Hofer considered previously existing terms to be inadequate and felt the need to create an entirely new word, a word that, in turn, gained increasing currency in Europe, suggests that something new-a new way of feeling or a new way of thinking about an old feeling - was entering the world. Indeed, it will be argued here that nostalgia is a distinctly modern word, an idea dependent on a way of worlding that is distinctive to modernity.

In due time, the disease came to be associated increasingly with groups-

Marcos Piason Natali is a professor in the Department of Literary Theory and Comparative Literature at the University of São Paulo in Brazil. His dissertation, defended at the University of Chicago in 2000, is entitled "The Politics of Nostalgia: An Essay on Ways of Relating to the Past." 
inside and outside of Europe - that had been incompletely modernized, but by the second half of the nineteenth century the medical condition of nostalgia ceased to be diagnosed even among marginal populations. The word's life was over as a medical condition, as the conglomeration of symptoms previously associated with nostalgia was absorbed by other diagnostic categories and came to be connected with melancholia and, later, depression. Freed from scientific pretensions, however, the word invented by Hofer in the seventeenth century would migrate to other arenas, as it came to label forms of relating to the past that had survived the nineteenth century. These new incarnations of nostalgia are the subject of this essay.

The word nostalgia would come to be used increasingly as a means of representing problems of a different sort, namely ones related to politics and empiricism. The force of the term's accusatory energy would be based not on medical discourse but on ideas about politics and history, as these were expressed in philosophies of history, in political discourse, and in psychoanalytic theory. In effect, the word was transformed from a disease of memory — one of the maladies de la mémoire-into a problem of the imperfect assimilation of the categories and practices of history, that is, the condition of those who did not have what in modernity gradually became the dominant relationship to the past. Nostalgia thus became a label used to define those who fell outside of the modern framework. ${ }^{1}$

Mostly through reading Marx, though the initial discussion will take us briefly to Kant and Hegel's writings on history, this essay follows the transformation of nostalgia as it became a term employed to charge attachment to and affect for the past with being both politically reprehensible and empirically untenable. Both charges depended on a particular understanding of the proper way of relating to the past: it was only after history was understood as necessarily emancipatory, progressive, and rationally comprehensible that affect for the past could come to be condemned as an irrational obstacle.

In a series of essays written between 1784 and 1798 and concerned specifically with history and its meaning, Kant characterized the Enlightenment as an expansion of knowledge made possible by man's courage to refuse the tutelage of others and use reason freely (3). Kant acknowledged that this new world of reason would bring dangers and difficulties-for him, this was always the case whenever one moved from servitude to freedom-and accepted that the psychological tension resulting from this transition would often manifest itself as longing for an earlier, simpler time (59-60). However, there is no room in Kant's thought for doubt regarding the desirability of this transformation of the world; although on an individual level rationalization and progress could indeed be the source of pain, they were justified collectively due to their role in leading humanity towards a better state. Ultimately, the "empty yearning" for simplicity—a sentiment fueled by reports from European travelers about "simpler" societies-would melt away as the benefits of reason became perceptible to all.

Although not without its outspoken and forceful critics, the view of history as the narrative of progress toward an improved state would become increasingly dominant in the nineteenth century. Earlier, however, it was still one among many 
competing approaches to history existing in Europe. When writing about the course of history, then, Kant, like Hegel after him, felt the need to defend the validity of progress and argue against other fundamentally different understandings of the course of history. One of these-history determined by chance-would be described by Hegel in his lectures on the philosophy of history as nothing less than "monstrous." This arbitrariness was to be countered by a history ordered by reason, and it was philosophy's duty to uncover its rules (36).

Both Kant and Hegel also argued against another way of understanding history: history as regression or fall. For Hegel, human beings were at first ruled by violent and unjust natural impulses, most of which were seen as incompatible with freedom, Hegel's ultimate goal. Gradually, these instincts were domesticated by consciousness, a fact historical research verified:

We owe to the interest which has occasioned these investigations [of ancient peoples], very much that is valuable; but this investigation bears direct testimony against itself, for it would seem to be awaiting the issue of an historical demonstration of that which is presupposed by it as historically established. That advanced condition of the knowledge of God, and of other scientific, e.g. astronomical knowledge (such as has been falsely attributed to the Hindus); and the assertion that such a condition occurred at the very beginning of History-or that the religions of various nations were traditionally derived from it, and have developed themselves in degeneracy and depravation (as is represented in the rudely-conceived so-called "Emanation System"); - all these are suppositions which neither have, nor-if we may contrast with their arbitrary subjective origin, the true conception of History - can attain historical confirmation. (58-59)

Scientific inquiry into ancient and non-European history - the two are conflatedwould reveal that individual societies did not regress from a golden age into a present state of decay. Studies, if undertaken with precision, would reveal the general state of lack in places unlike the European present, ultimately humbling the very objects of their inquiry. Kant had likewise been convinced that increased study of the past would demonstrate that humanity was unmistakably progressing; he attributed the perception of history as a fall from an ideal golden age to an imperfect state to the difficulty, from a limited perspective, of identifying the laws of human development. These laws were not immediately clear even to him, Kant admits, just as they were not for many of his contemporaries; in fact, Kant claimed, nothing seemed constant except inconstancy (141-142). This was not proof of the lack of meaning in history, however, but rather of philosophy's failure to recognize the appropriate signs indicating the laws of historical development.

Certain general tendencies toward improvement in human nature could nonetheless be detected, Kant argued, and they were to be excavated for the sake of laying bare something similar to what Hegel would call humanity's "impulse of perfectibility" (54). The work of uncovering these tendencies was seen by Kant as the fundamental obligation of the philosopher. More than any other event in ancient and recent history, it was the French Revolution of 1789 that had ultimately convinced Kant of humanity's capacity for improvement, offering him a source of continuous hope. In 1789, humanity's most noble instincts had been made mani- 
fest and had prevailed - albeit still in imperfect form. It was because of the French Revolution and the enthusiasm it had generated that Kant could see through the apparent inconstancy and declare that "the human race has always been in progress toward the better" (143-147).

Hegel claimed the principle of perfectibility was always received unfavorably by those who professed the timelessness and enduring stability of their regimes. It was also opposed by traditional religion, to which Hegel responded that once the mutability of worldly things was determined a choice had to be made between two positions: religion could either claim to inhabit another, non-worldly plane or ascribe the changes and imperfections in its institutions to the imperfection of its human members (54). It would later become clear, however, that the idea of human perfectibility was not so much a break with the Judeo-Christian tradition but rather a form of its secularization. The sacred Judeo-Christian temporality - time-as-anticipation-gave way to a secular but still future-oriented temporality in which faith in salvation was replaced by reliance on reason and the expectation of freedom, as argued by Johannes Fabian in Time and the Other. The improvement expected to come from an increase in knowledge was to be cumulative, progressing toward the final realization of freedom in its universal form. In this way, secular history substituted Judgment Day and eternal happiness with other goals, leaving the teleology relatively intact but replacing the eschatological wait for the end of the world by the promise of freedom.

\section{Nostalgia Is Bad Politics}

With the peculiar spin Marx would give Hegel's principle of perfectibility, the yearning for the past dismissed by both Kant and Hegel was no longer primarily an intellectual shortcoming; it became an explicitly political problem-an obstruction to social justice. For Marx, the world was not only moving towards greater individual freedom and scientific development but, more significantly, towards a more just society. Such a perception would lead Marx to thunder famously in 1852: "Let the dead bury their dead" (Reader 597), and the phrase haunts various currents of leftist thought to this day. The message it holds - that those interested in promoting social justice should not focus on the past-transformed nostalgia into a sort of political crime, causing well-intentioned leftists of several varieties to flee even the appearance of any connection to nostalgia. The very word traditionally used to refer to the left in English and other European languages-variations of "progressive"-emphasizes commitment to the future, while the words that describe the left's adversaries- "conservative" and "reactionary"- - suggest devotion to the past. ${ }^{2}$ As many of us within and outside of Europe at one point learned from Marx, that which was coded as the past was precisely what needed to be overcome and any desire to preserve it was highly suspect.

Often the suspicion came from the assumed connection between nostalgia and the preservation of privilege. This was the case, for instance, with the editors of a special issue of History Workshop dedicated to nostalgia. Malcolm Chase and Christopher Shaw mention, as examples of situations that elicit nostalgia, the fall of 
an empire or a privileged class's loss of status (15). ${ }^{3}$ Even the difficulty in imagining that the life of subaltern classes may change for the worse is itself a sign of the dominance of the ideology of modernization. For Marx, for instance, it is not only an aristocracy's mournful attachment to the past, with its obvious interests, that is to be questioned, but also any sector of society that rejects development:

The lower middle class, the small manufacturer, the shopkeeper, the artisan, the peasant, all these fight against the bourgeoisie, to save from extinction their existence as fractions of the middle class. They are therefore not revolutionary, but conservative. Nay more, they are reactionary, for they try to roll back the wheel of history. (Reader 482)

Marx's particular understanding of historical development allowed him to transform the conflict between, on the one hand, peasants, artisans, and the lower middle class and, on the other, the bourgeoisie, into a struggle between the past and the future. Although the metaphor that ends the passage quoted above refers to "rolling back the wheel of history," note that the previous sentence had described how the "reactionary" elements of society were defending not the past but their very existence, something which must by definition be in the present. The present way of living of small manufacturers and merchants, the lower middle class, artisans, and peasants had to be projected into the past, at which point they could be contrasted with a bourgeoisie projected into the future.

Marx's argument against attachment to the "past" does not derive its authority primarily from the claim that the attachment contradicts the natural order of things and upsets a historical law. Rather, the force of his critique lies above all in the assertion that those attached to the past desire a world which is less just. Those devoted to the past-or, as we have seen, to that which becomes coded as the past-inhibit history's progressive movement towards less exploitative modes of production. Marx's critique, therefore, is first and foremost of a political nature, based as it is on a concern for social justice, and it is this thrust of the critique that would receive various forms in modern critical thought. Consider, for instance, the following question posed by David Harvey: "Can the political and social identities forged under an oppressive industrial order of a certain sort operating in a certain place survive the collapse or radical transformation of that order?" (40). Harvey's "immediate answer" is that they cannot, yet for the interests of this discussion it is the subsequent analogy that is most illustrative: working-class movements seeking to perpetuate their social identities are like "women who have acquired their sense of self under conditions of male violence" and "return again and again to living with violent men" (40).

It is within the framework sketched above that the most thorough critic of capitalism we have could make the move towards the celebration of the triumph of capital. Marx welcomed the rise of capitalism in Europe and elsewhere first of all because it was understood to be the replacement of more oppressive forms of organizing society. Today, readers who approach Marx unawares, expecting to find a rabid critic of capitalism and the bourgeoisie, may be surprised to encounter instead a thinker who celebrates the triumph of the bourgeoisie in no uncertain 
terms: productive forces were liberated, reason defeated superstition, nature was dominated by humans - all of which was made possible by the spread of bourgeois ideology. In the process, the bourgeoisie "rescued a considerable part of the population from the idiocy of rural life" and removed the veil that prevented exploitation from being seen for what it was. The spectacular nature of the bourgeoisie's transformation of the world is made explicit in a passage from the Communist Manifesto:

The bourgeoisie, by the rapid movement of all instruments of production, by the immensely facilitated means of communication, draws all, even the most barbarian, nations into civilization. The cheap prices of its commodities are the heavy artillery with which it batters down all Chinese walls, with which it forces the barbarians' intensely obstinate hatred of foreigners to capitulate. It compels all nations, on pain of extinction, to adopt the bourgeois mode of production; it compels them to introduce what it calls civilization into their midst, i.e., to become bourgeois themselves. In one word, it creates a world after its own image. (Reader 477)

The alternative offered by capital is death: "on pain of extinction," every society is called upon to fashion itself in the image of the bourgeoisie. In this reading, the process, violent as it may be-and for Marx it undoubtedly is-is desirable, necessary, and inevitable.

Eighteenth- and nineteenth-century liberal ideologies did not differ drastically from Marx in this respect. As Christopher Lasch has demonstrated, liberal thinkers also condemned nostalgia in the name of historical progress, indicating that the left does not have a monopoly on the commitment to the future. The difference, however, is that the liberal view was in accord with Kant's belief in constant improvement but distanced itself from Hegel's impulse of perfectibility: liberalism advocated steady economic and social growth without the perspective of any radical change in the historical horizon. The ideology of progress and social development here becomes a means of justifying the very existence of capitalism, maintaining at times that it in effect represents the final stage of historical development.

The difference between Marx and the apostles of capitalism, of course, is that for Marx the rise of the bourgeoisie is looked upon favorably not only because it represents a step beyond previous historical formations, but also because it will allow for the rise of the proletariat and will ultimately install the very conditions for its undoing: "What the bourgeoisie, therefore, produces, above all, is its own grave-diggers" (Reader 483). The situation created by the bourgeoisie would eventually become impossible to sustain and its contradictions would result in capitalism's downfall. Capitalism would finally be superseded by a mode of production that would bring to an end the exploitation of humans by other humans. Marx's devotion to the future thus rested on the conviction that it was destined to bring about the emancipation of the working class and, by extension, of all of humanity. Capitalism, inaugurated economically by the English Industrial Revolution and politically by the French Revolution, was to be the last antagonistic mode of production, the last social system determined by class struggle, the last organization based on the exploitation of entire groups of people, and, in short, the last 
form of servitude. It would be "cast off," Marx claimed, "like a skin" (Reader 291). It was only after the bourgeois mode of production was claimed to have triumphedat least in advanced economies, since the rest of the world would follow in due time-and communism had been anointed as its necessary successor, that all other ways of organizing society could be coded as part of an unjust past. ${ }^{4}$ In lines that echo Kant's words about the inevitability of a transitional period of tension in the passage from servitude to freedom, Marx would write that:

We say to the workers and the petty bourgeois: It is better to suffer in modern bourgeois society, which by its industry creates the material means for the foundation of a new society that will liberate you, than to revert to a bygone form of society which, on the pretext of saving your classes, thrusts the entire nation back into medieval barbarism. ("Montesquieu LVI" 266)

Although this line of Marx's thought can be traced to "The German Ideology," the "Grundrisse," and the Communist Manifesto-as it was above-it is in "The Eighteenth Brumaire of Louis Bonaparte" that Marx is most forceful—and, one might add, most lyrical — about the need to abandon the past in the interest of justice. For the true revolution to be possible, imagination had to concentrate on the future: "The social revolution of the nineteenth century cannot draw its poetry from the past, but only from the future. It cannot begin with itself, before it has stripped off all superstition in regard to the past" (Reader 597). The contrast, here, is between the revolution to come and the events between 1848 and 1851 in France, when the attempt to draw poetry from the past-from 1789-resulted in a farcical failure.

Note that in Marx's formulation the element that must be done away with, in the relationship with the past, is "superstition," and it is at this point that Marx will make the call, cited above, for the burial of the dead to be left to the dead themselves. A close reading of "The Eighteenth Brumaire," however, reveals that the brunt of Marx's critique is directed not at what has passed-that is, after all, to be ignored by the living - but at what has remained. Marx's concern is with those who cling obstinately to ways of being that he defines as part of the past, like the peasants cited above who sought to defend their existence from extinction. Within bourgeois society itself, these elements from earlier social formations will be found, although in "stunted" or "travestied" form, as "unconquered remnants" of the past (Reader 241).

Those who inhabit such spaces are walking dead; they are "alive as if they were dead," to use the phrase Cuban author José Lezama Lima used to describe himself (Vitier 533). They are akin to those Dipesh Chakrabarty called the "living dead in our midst," those who wait "for death to realize in a physical form the "fact' of their obsolescence" ("Marx" 64). In a 1992 testimonial novel, Indian writer Amitav Ghosh describes what he believes to be the consequences, for a group of late-twentieth-century Egyptian villagers, of internalizing just such an ideology:

I had an inkling then of the real and desperate seriousness of their engagement with modernism, because I realized that the fellaheen saw the material circumstances of their lives in exactly the same way that a university economist would: as a situation that was shamefully anachronistic, a warp upon time; I understood that their 
relationships with the objects of their everyday lives was never innocent of the knowledge that there were other places, other countries which did not have mudwalled houses and cattle-drawn ploughs, so that those objects, those houses and ploughs, were insubstantial things, ghosts displaced in time, waiting to be exorcized and laid to rest. (200-201)

If here the objects of everyday use are described as ghosts, their owners, Ghosh's villagers, are Chakrabarty's "living dead." The drama of the situation is made clear by the fact that, in both Ghosh and Chakrabarty's descriptions, people are said to wait for the physical realization of their death and with it the final exorcism of their spectral beings. For Marx, these obstinate elements within modernity, coded as ghostly remnants of the past, are the weight that keeps society from progressing. If the burial of the dead is to be ignored, then, it is the chilling idea of the burial of these living dead, the not-yet truly dead, that Marx calls us to perform.

The fact that these metaphorical burials are seen as not only necessary but also inevitable is what Michel Rolph-Trouillot, after François Furet, calls the "second illusion of truth"- that is, the idea that "what happened is what must have happened" (107). Kant, Hegel, and Marx sought to convince their readers precisely of the inevitability of their historical narratives. Furthermore, as I have argued, for all three thinkers not only was what happened-or, and this is crucial, what would happen - inevitable, it was also desirable. Thus, any critical potential contained in sentiments such as nostalgia becomes immediately suspect, and eventually both capitalists and their fiercest critics could be seen embracing different forms of the idea of progress. Such a way of thinking produced peculiar couplings, as people who otherwise had very little in common seemed to be quite close in their appreciation of economic and social evolution. Marxist critic E. J. Hobsbawn, for instance, after reiterating that, indeed, "human history was an ascent, rather than a decline or an undulating movement about a level trend" (278), offers his contribution to a critique of nostalgia, in the process dismissing any non-progressive critique of the present:

Compared to these relatively coherent ideologies of progress, those of resistance to progress hardly deserve the name of systems of thought. They were rather attitudes lacking a common intellectual method, and relying on the acuteness of their insight into the weaknesses of bourgeois society and the unshakable conviction that there was more in life than liberalism allowed for. Consequently they require relatively little attention. (290)

These lines-particularly the claim that the resistance to progress deserved little attention-place Hobsbawn in the unlikely company of Lord Cromer, colonial administrator of Egypt and India, who expressed a similar view in the late nineteenth century:

We need not always inquire too closely what these people, who are all, nationally speaking, more or less in statu pupillari, themselves think is best in their own interests .... [I]t is essential that each special issue should be decided mainly with reference to what, by the light of Western knowledge and experience, . . . we conscientiously think is best for the subject race. (qtd. in Ghosh 91) 
And what was best for the subject race was, in a circular argument, Western knowledge and experience.

Hobsbawn shares with those who resist progress the conviction that capitalism is not satisfactory, yet in the latter's "attitude" the insight, which may in itself be "acute," is ultimately misguided. Nostalgia, like religion for Marx, is in fact a symptom of the real unease caused by an unjust society, a condition that would disappear as soon as the underlying cause of the dissatisfaction was done away with. For Hobsbawn and others, it is difficult to even imagine that logical thought would not lead a reasonable person to embrace the benefits of development and abandon attachment to the "archaic." The rejection of such logic was often met with bewilderment, as when Hobsbawn himself asked with astonishment how a servant girl could have left England and her "excellent employers" to return home to serfdom in Estonia (169). In Carlos Fuentes's novel Cambio de piel, a comparable question about very different historical circumstances is met with similar silence: "Or does anyone in fact believe that it would have been better to defeat the Spaniards and continue subjected to the fascism of the Aztecs?" (472). With a complacent grin, the question assures us that no one could actually prefer to live in the pre-colonial society destroyed by the Spanish. In both cases, the choice is presented as that between an unjust past-the Aztecs, Estonia-and a superior present-the Spanish, England. (It is of course a common move of Western thought to depict the critique of progress precisely in the way that Fuentes anachronistically described it: fascism.) In this framework, Marxism will often answer the question "Why would someone wish to return?" by appealing to such notions as false consciousness and alienation, ultimately removing desire for the past from the realm of logical and ethical possibility.

\section{Nostalgia Is Bad History}

The critique of the politics of nostalgia outlined above is based on the belief that history is the narrative of progress towards an improved state. Yet the indictment of nostalgia as bad politics has also been supported by another belief, and it too may be gleaned through reading Marx. The view is summarized most famously in the opening lines to "The Eighteenth Brumaire," where Marx amends Hegel's famous statement that historical events happen twice by adding that they occur first as tragedy, then as farce. Here Marx is referring specifically to what he saw as the misguided belief, in nineteenth-century France, that it would be possible to replicate the 1789 Revolution. He uses the events between 1848 and 1851 to formulate a materialist conception of history that stresses the inevitability of progress, as outlined above, and, consequently, the impossibility of the repetition of the past. What the French had in 1851 was therefore only a ghost of the 1789 Revolution and a caricature of the true Napoleon, both of which were born of the misdirected and ultimately impossible desire to relive the past (Reader 594-597).

That Marx chooses to use the historical example of the French Revolution to illustrate the impossibility of repetition could not be more appropriate. The idea of 
a break with the past, after which the present became incommensurable with the past, spread after the shock of the French Revolution. For Marx, this development was to be celebrated, and one even has the sense, in reading "The Eighteenth Brumaire," that, despite the grief Marx felt about the failure of 1848, he ultimately saw it as the bitter yet necessary medication required for the French to overcome the illusion that they could repeat the past. After 1848, then, the past could be seen as definitively dead, since even its ghosts had been subdued, bringing about exclusive focus on the future and its possibilities.

However, the survival of affectionate attachment to the past in the second half of the nineteenth century and into the twentieth century upset Marx's narrative, and as late as 1915 it was still deemed necessary to formulate a similar critique of nostalgia, though with another vocabulary. In that year Freud published "Mourning and Melancholia," a text that, I venture, may be read in light of nineteenthcentury struggles over ways of relating to the past. As in the eighteenth century, here a version of nostalgia continues to define abnormality: while mourning is the healthy reaction to loss, melancholia is pathological. In the former, after a series of "reality checks," the mourner accepts that the lost object of affection indeed no longer exists and that no amount of effort will make it return. The mourner's desire to live then slowly forces him to detach himself from the object, move on, and acquire a new object of affection. This "working through" is the healthy response to loss, one opposed to melancholia's regressive impulse and pathological inability to progress. When faced with a melancholic subject, Freud's work of mourning "impels the ego to give up the object by declaring the object to be dead and offering the ego the inducement of continuing to live" (252). The first step, then, is recognizing that the object, like Marx's 1789 Revolution, cannot be resurrected.

That Freud called upon the subject to accept the death of the object revealed his devotion to a particular way of understanding death. This belief in the finality of the death of the lost object is of fundamental importance for the subsequent critique of nostalgic attachment. There is no repetition of the past, for Freud as for Marx, precisely because the dead-Danton, Robespierre, our loved ones-do not return. The belief that the dead have no contact with the living is necessary in order for the call for the abandonment of the dead to be justified. Attachment to the past becomes a hindrance precisely because of the belief that the past is irreparably lost, making nostalgia a desire without the possibility of fulfillment. The belief in this impossibility is essential for the existence of nostalgia. (Conversely, diagnoses of nostalgia would be inappropriate in places where there is a belief in the presence of the past and the return of the dead.)

For Freud and his "reality checks," however, this is a question not of beliefs but of empiricism; the weight of the real is itself enough to push the melancholic subject toward the appropriate conclusion. While the critiques of nostalgia outlined above rested upon a particular understanding of social development, this distinct denunciation allows us to sketch a line of reasoning that censures nostalgia through evoking modern notions of truth. Nostalgia, here, is faulted for its inaccuracy and is accused of promoting views of the past that are empirically untenable. While the view of nostalgia as politically sinister is based on one series of 
oppositions-conservatism and progressiveness, servitude and freedom, reaction and progress - this critique depends on dichotomies such as fiction and fact, irrationality and rationality.

Consider, as an example, Raymond Williams's The Country and the City. This study addresses the one hundred years after 1750 in England, the period in which landowners appropriated a large part of the English countryside and enclosures pushed waves of peasants into growing urban centers. Through focusing on the sorrowful literary responses to this development in such authors as Wordsworth and Blake, Williams in effect writes a sort of social history of literary nostalgia. His purpose in the book, as he defines it, is to uncover the "real social relations" of the time being longed for, in the process revealing that the actual past had been clouded by the idealized scenes of the pastoral (66). And when an earlier economic system is analyzed with the tools of social science, instead of the untrustworthy literary imagination, what does one find? A clear reply can once again be found in Marx, this time in "The British Rule in India":

[W]e must not forget that these idyllic village communities, inoffensive though they may appear, had always been the solid foundation of Oriental despotism, that they restrained the human mind within the smallest possible compass, making it the unresisting tool of superstition, enslaving it beneath traditional rules, depriving it of all grandeur and historical energies .... We must not forget that this undignified, stagnatory, and vegetative life, that this passive sort of existence evoked on the other part, in contradistinction, wild, aimless, unbounded forces of destruction and rendered murder itself a religious rite in Hindostan. (Reader 658)

In the previous passage, if "feudalism" were substituted for "Oriental despotism," much of the description could have been in Williams's book about the English countryside. "We must not forget," Marx insists in the passage, defining the problem as one of remembering accurately. Despite their idyllic appearance, these Indian villages were actually the very cradle of injustice.

Williams's main concern in his study of the pastoral is similar: we must not forget what eighteenth-century England was actually like. Its story must be narrated accurately and its portrayal must be truthful. Nostalgia, then, is a misguided and romantic longing for a place which, historical data shows us, never existed in the first place (37). The literary tradition of the pastoral is shown to be in fact an idealization of feudal values, with the labor and the laborers who support the social order obscured and forgotten. The inaccuracies of the images found in the pastorals are in this way uncovered, demonstrating that there was actually inequality in the utopian villages glorified by English writers.

Fredric Jameson virtually replicates this argument in his study of the way in which the 1950s were evoked in the United States in the 1980s. Nostalgia is again faulted for its lack of accuracy: the present tries to "focus the landscape of the past through nostalgia-tinted spectacles" (290). The image this sentimentality constructs is said to have little to do with the actual historical period, and even the visual elegance of "nostalgia films" is seen as a sign of their mystifying intentions. This is opposed, once again, to a more precise view of the world: economic analysis would reveal that "the deeper realities of the period" in fact do not correspond to 
our image of it (281). In contrast, the film Something Wild is praised precisely because it demonstrates that the nostalgic image of Middle America is false, that is, that "there is no longer anything to discover at the end of the line" (292).

That the images produced by longing are inaccurate is certainly significant. That social conflict and injustice are concealed in idealized representations of the past is undoubtedly important. However, the claim that a nostalgic perspective generates faulty historiography need not be the final word to be said about the issue. The fact that a reading of nostalgia may even be thought to be complete after proof is given that its representations of the past are distorted-after, in other words, nostalgia is shown to be something other than history-reduces the relation to the past to a problem of historiographic evidence. It suggests, ultimately, that history is the only legitimate way of narrating the past. (In the cases analyzed by Jameson and Williams, the charges are made of films and literary texts, works that do not even aspire to be history.) That nostalgic artistic works may even be faulted for failing to live up to historiographic standards of accuracy, verisimilitude, verifiability, and objectivity demonstrates the extent to which the imperialism of history's categories repudiates alternative relationships to the past.

In the essay "History's Forgotten Doubles," Indian psychoanalyst Ashis Nandy offers a bold statement of the effects of history's attack on other ways of relating to the past. Contrary to Kant and Hegel, Nandy writes at a time when history-an idea linked to the modern nation-state, secularism, scientific rationality, progress, and development-has become dominant on a global scale. He describes the process through which history came to define as illegitimate those relationships to the past that fell outside scientific rationality and the secular worldview. Gradually, the imperialism of history's categories was such that it was claimed that no past should be independent of history. (If my reading is correct, this is what occurs in the passages from Williams and Jameson analyzed above.) Even if a particular society did not have a historical tradition, had not written its own history, and was not primarily secular and disenchanted, it would not be too difficult to write that community's history. This history, in turn, would undoubtedly be rational, secular, and progressive, regardless of the way the past was understood locally, as argued by Chakrabarty in Provincializing Europe.

This essay has attempted to demonstrate that for the term nostalgic to be used as critique, as it so often has been in modern thought, certain conventions have to be in place. It is because of the twin beliefs in the promise of the future and the irreversibility of time that nostalgia can be seen as harmful to an individual's wellbeing and to a collectivity's welfare. It is only if history is understood as necessarily emancipatory, progressive, and rationally comprehensible that affect for the past can be immediately condemned as an irrational obstacle hindering the pursuit of social justice; it is only if the past is thought of as forever lost and death is seen as final that a desire for repetition can be seen as unrealistic. Likewise, it is only after historiography becomes the dominant means of approaching the past that nostalgia may be faulted for its inaccuracy. These were the preconditions for the critique of attachment to the past as politically counter-productive in nineteenthand twentieth-century thought. 
Caught in such a web, many good leftists have found themselves in a quandary difficult to solve. A close reading of The Country and the City, for instance, reveals passages with clear nostalgic undertones, despite Williams's efforts to distance himself from any uncritical longing for bygone days. In one early passage, Williams reveals that he, too, was born in a remote village in the country, and that therefore, for him, "before the argument starts, country life has many meanings":

It is the elms, the may, the white horse, in the field beyond the window where I am writing. It is the men in the November evening, walking back from pruning, with their hands in the pockets of their khaki coats; and the women in headscarves, outside their cottages, waiting for the blue bus that will take them, inside school hours, to work in the harvest. It is the tractor on the road, leaving its tracks of serrated pressed mud; the light in the small hours, in the pig-farm across the road, in the crisis of a litter; the slow brown van met at the difficult corner, with the crowded sheep jammed to its slatted sides; the heavy smell, on still evenings, of the silage ricks fed with molasses. (2-3)

Much of Williams's work may be read through the tension between the yearning for the preservation of practices such as those described with such tenderness in these lines and the urge to criticize an unjust social order. Hence, while his study of the pastoral reveals the imprecision of the poems' images, the preface to the same study, like Williams's fictional work, allows for more lyrical and generous constructions. Thus, to David Harvey's question regarding the possibility of the survival of previous social identities, Williams's answer would probably have been more ambivalent. Of his novel People of the Black Mountains, for instance, Williams wrote:

The defeats have occurred over and over again, and what my novel is then trying to explore is simply the condition of anything surviving at all. [...] It's the infinite resilience, even deviousness, with which people have managed to persist in profoundly unfavourable conditions, and the striking diversity of beliefs in which they've expressed their autonomy. A sense of value which has won its way through different kinds of oppression of different forms ... an ingrained and indestructible yet also changing embodiment of the possibilities of common life. (qtd. in Harvey 29)

Williams resists the impulse, present in many Marxist critiques, to simply project his hopes and aspirations into the future, away from the elms and white horses, away from the women with headscarves and the cottages, away from the sounds of a litter of pigs. The conflict is unresolved and in his theoretical work it becomes the tension between a "militant particularism" devoted to the preservation of local identities and a socialist "universalism" that has no place for the concern with historical and social singularity.

For many leftist thinkers, this fondness for the past and the local is invariably accompanied by guilt, since renouncing such sentimentality is, according to Marx, precisely the committed critic's obligation:

[W] hatever bitterness the spectacle of the crumbling of an ancient world may have for our personal feelings, we have the right, in point of history, to exclaim with 
Goethe:

Should this torture then torment us

Since it brings us greater pleasure?

Were not through the rule of Timur

Souls devoured without measure? (Reader 658)

Politics is here apparently separated from the private sphere and from affect, and individual pain, echoing Kant, is justified in the name of an improved collective future. Williams at once follows and rejects this cue, with the wistful prefatory pages- "it is as well to say at the outset that this has been for me a personal issue" (2) - coexisting with the subsequent analysis that exposes the fallacy of narratives based on similar emotions and condemns pastoral writers for adopting a tone not altogether different from that of his preface.

Within the developmentalist framework outlined above, the only shape this fondness for the past could take would be conservatism or, as Freud proposed, melancholia. It should be noted at this point that for Freud the melancholic person is not delusional or mistaken. In fact, "it is merely that he has a keener eye for the truth than other people who are not melancholic .... [I]t may be, so far as we know, that he has come pretty near to understanding himself; we only wonder why a man has to be ill before he can be accessible to a truth of this kind" (246). Those who are melancholic, then, are actually quite lucid, recognizing the "reality" of death and avoiding what Pascal called divertissement - the diversions devised in order to avoid thinking about death: "Being unable to cure death, wretchedness and ignorance, men have decided, in order to be happy, not to think about such things" (66). The melancholic do think about such things-constantly, obsessively-yet they conclude that death and loss are indeed irreparable and are therefore understandably overcome by grief.

This structure is only valid, it should now be clear, in a disenchanted setting. This is, at least, how I understand Kristeva's claim that the melancholic are necessarily atheistic (14). Only a profound disenchantment allows for the despondent grief that accompanies melancholia: "[M]elancholy persons manifest a strange memory: everything has gone by, they seem to say, but I am faithful to those bygone days" (60). Both of these clauses must be present in order for nostalgia to occur: not only "I am faithful to those bygone days," but also "everything has gone by." If one does not believe that everything has gone by, and if one is not atheistic and disenchanted, then a different conceptual territory emerges. We would in that case be in the presence of something other than nostalgia, melancholia, or even mourning; that vocabulary, along with the political critique of nostalgia, would therefore lose its ground.

\section{Notes}

${ }^{1}$ As early as the eighteenth century there was already, of course, uneasiness over the feverish pursuit of novelty. Yet this criticism was not scientifically sanctioned in the way that the condemnation of nostalgia was, in its alignment with nascent scientific disciplines. Although the use of the term nostalgia spread to the medical discourse of a variety of 
European languages, a term such as nostophobia or even a concept to describe pathological fear of the past or unhealthy devotion to the future never entered the European vocabulary.

${ }^{2}$ The word "radical," as Françoise Meltzer pointed out to me, is a dissonant example in this respect. While its origins refer to roots (and hence the past), in English it has come to be associated primarily with leftist political activity. In various Romance languages, it refers to "extreme" politics of any sort.

${ }^{3}$ According to Chase and Shaw's own account, this led to their knee-jerk hostility toward nostalgia when planning a conference on the topic in Leeds in 1985: "Of all the ways of using history, nostalgia is the most general, looks the most innocent, and is perhaps the most dangerous," Chase warned the conference (1). In retrospect, the two authors admit that their "understanding of nostalgia was rather combative, therefore: we wished to explore a cultural phenomenon that told us about the present through its falsification of the past" (1). This initial impulse, however, would be questioned as they explored the distinct manifestations of nostalgia and, in an approach more in line with this paper's arguments, realized the way in which nostalgia was embedded in a specific epistemological context.

${ }^{4}$ Through, for instance, defining them as part of the Asiatic, ancient, or feudal modes of production (Reader 5) or the tribal, communal, or feudal forms of ownership (151-152).

\section{Works Cited}

Chakrabarty, Dipesh. "Marx after Marxism: History, Subalternity and Difference." Marxism Beyond Marxism. Ed. Saree Makdisi, Cesare Cesarino, and Rebecca E. Karl. New York: Routledge, 1996. 55-70.

-. Provincializing Europe: Postcolonial Thought and Historical Difference. Princeton: Princeton University Press, 2000.

Chase, Malcolm, and Christopher Shaw. "The Dimensions of Nostalgia." The Imagined Past: History and Nostalgia. Ed. Chase and Shaw. Manchester: Manchester University Press, 1989. 1-7.

Fabian, Johannes. Time and the Other: How Anthropology Makes Its Object. New York: Columbia University Press, 1983.

Freud, Sigmund. "Mourning and Melancholia." The Standard Edition of the Complete Psychological Works of Sigmund Freud. 24 vols. Trans. James Strachey. London: Hogarth Press, 1964. 14: 239-258.

Fuentes, Carlos. Cambio de piel. Barcelona: Seix Barral, 1991.

Ghosh, Amitav. In an Antique Land. New York: Vintage Books, 1992.

Harvey, David. Justice, Nature and the Geography of Difference. Malden: Blackwell Publishers, 1996.

Hegel, Georg Wilhelm Friedrich. The Philosophy of History. Trans. J. Sibree. New York: Dover Publications, 1956.

Hobsbawn, E. J. The Age of Revolution, 1789-1848. New York: New American Library, 1962.

Hofer, Johannes. "Medical Dissertation on Nostalgia." Trans. Carolyn Kiser Anspach. Bulletin of the History of Medicine 2 (1934): 376-391.

Jameson, Fredric. Postmodernism, or, The Cultural Logic of Late Capitalism. London: Verso, 1991.

Kant, Immanuel. On History. Trans. Lewis White Beck, Robert E. Anchor, and Emil L. Fackenheim. Indianapolis: Bobbs-Merrill, 1963.

Kristeva, Julia. Black Sun: Depression and Melancholia. Trans. Leon S. Roudiez. New York: Columbia University Press, 1989.

Lasch, Christopher. The True and Only Heaven: Progress and Its Critics. New York: Norton, 
1991.

Marx, Karl. The Marx-Engels Reader. Ed. Robert C. Tucker. New York: Norton, 1978.

- "Montesquieu LVI." Collected Works. 49 vols. New York, International Publishers, 1975. 8:254-268.

Nandy, Ashis. "History's Forgotten Doubles." History and Theory 34 (1995): 44-66.

Pascal, Blaise. Pensées. Trans. A. J. Krailsheimer. London: Penguin Books, 1966.

Rolph-Trouillot, Michel. Silencing the Past: Power and the Production of History. Boston: Beacon Press, 1995.

Vitier, Cintio. "Nueva lectura de Lezama." Crítica cubana. Havana: Editorial Letras Cubanas, 1988. 533.

Williams, Raymond. The Country and the City. Oxford: Oxford University Press, 1975. 